\title{
Batılı İki Seyyahın Kaleminden İstanbul Masalları: Cyrus Adler ve Allan Ramsay'nin Kahvehane Ziyaretleri
}

\author{
Melike Tokay-Ünal*
}

\section{Osmanlı İmparatorluğunda Kahvehane Kültürü}

Osmanlı İmparatorluğunda kahvehanelerinin "kamusal mekan” sayılarak sosyal hayatın bir parçası oluşu 16. yüzyıla dayanır. Kamuran Sami’nin de belirttiği gibi, ${ }^{1}$ Osmanlı İmparatorluğu 16. yüzyılda yaşadığı en parlak dönemden 20. yüzyılda dağılma ve yıkılma dönemine kadar sancılı bir süreç geçirmiş, ve bu süreç kamusal alanda gün geçtikçe yerini daha da sağlamlaştıran kahvehaneleri de etkilemiştir (s. 161). 16. yüzyılın ortalarında kamusal alandaki camii ve çarşı ikilisine bir alternatif olarak oluşan kahvehane, çoğunlukla camilerin yanına kurulmuş, namaz aralarında sohbet etmek ve dinlenmek isteyen cemaatin kahvelerini yudumlayıp namaz saatini bekledikleri bir mekan olarak betimlenebilir. Zamanla, bu sade ve gösterişsiz olarak tabir edebileceğimiz mekanlar Osmanlı kültürel zenginliğinin en önemli figürü haline gelmiştir. Kahve tüketilen mekan olduğu için kahvehane ismini alan bu kamusal mekan namaz aralarını bekleyen cemaat dışında Osmanlı İmparatorluğunun zengin sosyal yapısı içindeki diğer kesimlerden de ilgi görünce yapısal değişikliklere uğramıştır. Toplumun hemen her kesiminin uğrak yeri haline gelen kahvehaneler "sohbet ve dedikodu edilen, eğlenilen, dinlenilen, dini ve güncel tartışmaların yapıldığı ve halk hikayelerinin

\section{* Bilkent Üniversitesi}

I Kamuran Sami. "Halk Kültürü Bağlamında Kahvehanelerin Toplumsal ve Mekânsal Dönüşümleri Diyarbakır Kent Örneği”, Milli Folklor 20IO, Yıl 22, Say1 85:159-172. 
anlatıldı̆̆g” nargile içilen, tavla ya da başka oyunların oynandığı, zengin Osmanlı kültürünü temsil eden mekanlar haline gelmiştir (s. 159-172).

İstanbul'da cami yakınlarına kurulan küçük mahalle kahvehaneleri dışındaki ilk kahvehanenin 1554-1555 yıllarında Tahtakale semtinde "Halepli Hakem ve Şamlı Şems adında iki Arap kökenli tüccar" tarafından açıldığı bilinir. $^{2}$ Mısır Çarşısı'nın hemen arkasında yer alan Tahtakale, 16 . yüzyıl ortalarında İstanbul'un ticaret merkezidir. Bu bağlamda Arap kökenli iki tüccarın Tahtakale'de açtığı bu ilk kahvehane "tüccarların, gemicilerin, çeşitli eğlence sanatlarını icra eden oyuncuların, kayıkçı, hammal, tellak, rençber ve fırıncıların” (s. 25) uğrak yeri olmuştur. Bu tür çarşı ya da liman yakınında açılan kahvehaneler cami yakınında açılan mahalle kahvehanelerinden müşteri profili bakımından farklılık göstermiş olsa da kahve ve nargile eşliğinde yaşatılan kültür benzerdir. Ekrem Işın’a göre, "16. yüzyıldan itibaren Osmanlı gündelik hayatını sosyalleşme sürecine sokan belli başlı kültürel dönüşümler” (s. 34) yapısal olarak farklılık göstermelerine rağmen genel olarak kahvehanelerde yaşanır. Bu bağlamda kahvehaneler cami ve çarşı dışında kalan gündelik hayatı ve değişik sınıflardan, mesleklerden, dinlerden, ve kültürlerden insanların bu gündelik hayata katılımlarını anlamak açısından önem taşır. Genel anlamda kahve ve nargilenin tüketildiği bu mekanlarda farklı kesimlerden insanların dahil olduğu muhabbetler, oynanan oyunlar, ya da paylaşılan masallar-hikayeler o toplumun değer yargıları çerçevesinde şekillenmiştir. İstanbul'da değişik semtlerdeki kahvehanelerde bu değerler farklılık gösterse de ortak olan bir gerçek vardır: 16. yüzyıldan Tanzimat, Meşrutiyet ve erken Cumhuriyet dönemine kadar İstanbul kahvehaneleri İstanbul ahalisinin sosyo-kültürel yapısını betimlemeye yardımcı önemli öğelere sahiptir; ki bu öğelerden belki de en değerlisi bu kahvehanelerde anlatılan, kulaktan kulağa yayılan, batılı seyyahlar tarafından derlenen, yabancı dillerde kitap haline gelen masallar-hikayelerdir.

Kahvehaneleri kahve içilen, nargile ya da çubuk (sigara) tüttürülen, namaz aralarının mahalleli ile sohbetle geçirildiği bekleme salonları olarak tanımlamak başlı başına Osmanlı kahvehanelerine ve onları yaşatan sınıf, uyruk, dil ve dinen zengin Osmanlı halkına haksızlık olur. Kahvehaneler hem sohbet, hem eğlence mekanlarıdır; hem dini ve destani kitaplar okunur hem de tavla veya satranç gibi çeşitli oyunlar oynanır; hem meddahlar siyasi kıssalar anlatır hem

2 Ekrem Işın. "Kahve ve Kahvehanelerin Toplumsal Tarihi”, Tanede Saklı Keyif, Kahve, İstanbul: Yapı Kredi Kültür Sanat Yayıncılık, 200I:IO-43. 
de aynı siyaset gölge tiyatrosunun malzemesi olur ve kahvehane müşterisiyle buluşur $^{3}$ (s. 35).

Kahvehaneler Osmanlı kamusal alanına dahil olduğu andan itibaren siyasi sohbetlere ev sahipliği yapmıştır. Kimi zaman Saray ve Devlet-i Aliyye eleştirilir, kimi zaman da övgülere boğulurdu; kimi zaman kahvehane ahalisi aynı görüşte olur, övgüler ya da yergiler hep bir ağızdan dillendirilir, kimi zaman da karşıt görüşler ateşli tartışmalara sebep olur, kahvehaneler kavgalara sahne olurdu. İşte tam da bu gibi durumlarda kahvehanedeki bilge kişinin ortamdaki anlaşmazlığa bir hikayeyle son vermesi adet olmuştu. Bazen de açıla gelmiş bir sohbeti bağlamak, anlamlı bir noktaya erdirmek için de anlatırdı "bilge kişi”” hikayelerini (s. 5). İşte bu hikayeler-masallar bu çalışmanın baş karakterleridir ${ }^{5}$.

\section{Cyrus Adler ve Allan Ramsay'nin Kahvehane Masalları}

1890 ve 1891 yıllarında ziyaret ettikleri kahvehanelerdeki bu hikayeleri-masalları dinleyen Amerikalı, Sami Dilleri uzmanı ve din bilimci Cyrus Adler ve İskoçya kökenli, İstanbul doğumlu, İstanbul Tütün Rejisi idari amiri Allan Ramsay, 1898 yllinda bu hikayeleri derler ve Told in the Coffee House: Turkish Tales adiyla

3 Ahmet Yaşar. Osmanl Kahvehaneleri: Mekan, Sosyalleşme, İktidar, İstanbul: Kitap Yayınevi, 2009, s. 96 ve Işın, 200 I.

4 Sabri Kaliç. Ístanbul I898: Kahvehane Hikayeleri İstanbul: Maya Kitap, 2012.

5 Cyrus Adler ve Allan Ramsay'nin I898 yılında yayımladıkları kitaplarının orijinal ismi Told in the Coffee House: Turkish Tales'dır. "Tales" kelimesi 2012 yılında kitabın çevirisini yapan Sabri Kaliç tarafından "hikaye" olarak tercüme edilmiştir. "Tales" kelimesini hem "hikaye" hem de "masal" olarak tercüme etmenin daha doğru bir kullanım olduğunu düşünerek bu yazıda Adler ve Ramsay'nin kahvehanelerde dinleyip derlediği ve kitap olarak bastığı edebi türü hem "hikaye" hem de "masal" olarak nitelendirmek yanlış olmayacaktır. Bu yazıda "masal” kelimesi Güncel Türkçe Sözlükteki karşılığı "Genellikle halkın yarattığr, hayale dayanan, sözlü gelenekte yaşayan, çoğunlukla insanlar, hayvanlar ile cadı, cin, dev, peri vb. Varlıkların başından geçen olağanüstü olayları anlatan edebi tür, ”ve Orhan Acıpayaml’nın Halkbilim Terimleri Sözlüğündeki karşıllı̆̆ "İnsanoğlunun evren, dünya, yaşam, doğa, toplum, ve kendisiyle ilgili taribsel oluşum, düşün, istek ve izlenimlerinin az ya da çok değģ̧ikliğe uğrayarak ağızdan ağıza geçme yoluyla çağımıza ulaşan geleneksel anlatı örnekleri” anlamları çerçevesinde kullanılmıştır. "Hikaye” kelimesi ise Güncel Türkçe Sözlükteki karşıllğı “Gerçek veya tasarlanmış olayları anlatan düz yazı türü, öykü," ve Edebiyat ve Söz Sanatı Terimleri Sözlügündeki karşılığı "Hayalde tasarlanan meraklı bir takım olayları anlatarak okuyanda heyecan veya zevk uyandıran ve çoğu ancak bir kaç sayfa tutan yazi" anlamları çerçevesinde kullanılmıştır. Bu yazıda "masal" ve "hikaye" kelimeleri birbirlerinin yerine de kullanılmıştır. 
okuyucuyla buluşturur ${ }^{6}$. Adler ve Ramsay'nin kitabı 29 kısa masaldan oluşmaktadır. Kitabın başında, başlığın hemen altında "Cyrus Adler ve Allan Ramsay tarafından derlenip İngilizceye çevrilmiştir” ibaresi yer almaktadır (s. iii).

Kısa bir araştırma sonrası, Adler ve Ramsay'nin kahvehane masallarının 1914 'te Atlantik okyanusunu aşıp Londra’da İngiliz okurlarla buluştuğunu öğrenebiliriz. Told in the Coffee House: Turkish Tales kitabındaki hikayeler 1914 yılında Allan Ramsay ve Francis McCullagh tarafindan bir araya getirilip, Nasreddin Hoca masallarıla birlikte Tales from Turkey adıyla Simpkin, Marshall, Hamilton, Kent \& Co Ltd. yayınevince basılmıştır. Bu kitaba uzun ve açıklayıcı bir önsöz yazan yazar Francis McCullagh kitaptaki bazı hikayelerin Adler ve Ramsay'nin kahvehane ziyaretlerinde dinledikleri masallar olduğunu belirtir, ve Cyrus Adler'e bu masalların tekrar basılmasına izin verdiği için teşekkürlerini sunar.

Adler ve Ramsay'nin İstanbul kahvehaneleri hikayelerinin Atlantik'i aşıp New York'tan Londra'ya geçişi on altı yıl sürmüştür. McCullagh'nin de belirttiği gibi 20. yüzyılın başında British Museum'da, ki Londra'da bulunan British Museum dünyanın en zengin etnografya koleksiyonuna ev sahipliği yapmaktadır, "TürkOsmanlı folkloru" adı altında hiçbir eser bulmak mümkün değildir. Türk insanının da birçok millet gibi mizah anlayışı ve bu mizahı sunduğu hikayeleri olduğunu savunan McCullagh, British Museum'daki “Türk-Osmanlı folkloru” boşluğunu doldurmak amaciyla bu hikayeleri bir araya getirip basmaya karar verdiklerini kitabın önsözünde anlatmaktadır ${ }^{7}$ (s. ix). Bir diğer neden ise 20. yüzyılın başlarında artık ne İstanbul kahvehanelerinde ne de Anadolu kahvehanelerinde masal-hikaye anlatı geleneğinin sürdürülüyor olmasıdır. McCullagh modern Türk'ün masal anlatmaya ya da dinlemeye vakti olmadığını belirtir ve bu gelenek bütünüyle terkedilip bu masallar unutulmadan masalların derlenmesi ve yazılı olarak arşivlenmesi gerektiğini savunmaktadır (s. xix).

Told in the Coffee House kitabının basım tarihi olan 1898'ten 2012 yılına kadar, yani 114 yıl boyunca, New York ve Londra kütüphanelerini ve kitabevlerini ziyaret edip bu kitapla tesadüfen karşılaşan Türkler dışında hiçbir Türk 1890-1891 yıllarında Adler ve Ramsay'nin İstanbul kahvehanelerinde dinlediği masalları okumamıştır. Atlantik'in iki kıyısında da İngilizce basılan bu hikayeler

6 Cyrus Adler ve Allan Ramsay. Told in the Coffee House: Turkish Tales, New York: The Macmillan Company, I898.

7 Francis McCullagh ve Allan Ramsay. Tales From Turkey. London: Simpkin, Marshall, Hamilton, Kent \& Co Ltd., I9I4. 
2012 yılına kadar anlatıldığı orijinal dilinde basılmamıştır. 2012 yılında, Sabri Kaliç'in çevirisiyle İstanbul 1898 Kahvehane Hikayeleri adı altında Maya Kitap'tan basılan bu hikayeler, dillendikten ve dinlendikten 122 sene sonra tekrar Türkçeye çevrilmiştir. 1898'deki orijinal baskısında olduğu gibi 2012 baskısında da en başta Cyrus Adler'in 1 Şubat 1898'de Washington'da yazdığı önsöz bulunmaktadır. Bu önsözde Adler İstanbul kahvehaneleri gözlemini kısaca okuyucuyla paylaşır. Adler'e göre İstanbul'da ziyaret ettiği kahvehaneler,

genelde odadan birazcık büyük, duvarlarında cam paneller olan yerlerdir. Mobilya olaraksa cezve asacak tertibatı olan küçük bir sacayak ve kahve pişirmek için ateş bulunur. Üzerinde halı olan bir kerevet tüm duvar boyunca uzanır. Bunun üzerinde, sarıklı Türkler bacaklarını altlarına alarak oturur; nargile veya sigara tüttürür, kahvelerini yudumlarlar. Birkaçı tavla oynar ama geneli sohbetlere katılır (s. 5).

Bu hikayeler, 19. yüzyılın sonlarında kaybolmaya yüz tutmuş ve sonrasında da unutulmuş bir Türk geleneği olan masal-hikaye anlatı geleneğinin parçası olması yönünden okunmaya ve arşivlenmeye değerdir. Bunlar sayesinde masal anlatı geleneğinin yanı sıra Türk-Osmanlı kültürünün vazgeçilmez folklorik öğesi kahve ve kahvehanenin de tarihi önemi hatırlanmış ve irdelenmiş olur.

2012 yılında Radikal gazetesinde yayımlanan "Bir Orta, Bir de Sade"8 ve Boxer dergisinde yayımlanan "Eski İstanbul Kahvehaneleri"” adlı iki kitap tanıtım yazısı dışında Adler ve Ramsay'nin İstanbul kahvehanelerinde dinlediği masallar ve bu iki seyyahı İstanbul'a getiren sebepler hiçbir araştırmacının dikkatini çekmemiş olacak ki hiçbir akademik araştırmaya ya da esere konu olmamışlardır. Konu edildikleri bu iki popüler kültür yazısı da okuyucuyu yanlış bilgilendirmiş, referans göstermeden varsayımlarda bulunmuş, araştırma yapılarak öğrenilecek bir çok tarihi bilgiyi okuyucuya yanlış iletmiştir. Mesela, Radikal gazetesindeki yazıda Adler ve Ramsay'nin İstanbul'a gitme hikayesi tamamen yanlış olarak aktarılmıştır:

Adler'in uzun yıllar İstanbul'da yaşayan arkadaşı Ramsay'den dinlediği "kahvehane hikâyeleri" aklını kurcalayıp durmuş bir süre. Sonunda arkadaşı Ramsay’i de yanına alıp hikâyeleri derlemek üzere Osmanlı topraklarına gelmiş. İstanbul kahvehanelerini dolaşıp anlatılan hikâyeleri dinleyip derleyen iki arkadaş ülkelerine döner dönmez hikâyeleri kitaplaştırmışlar.

8 Ayşe Bengi. "Bir Orta, Bir de Sade", Radikal, ı3 Nisan 2012.

9 İsimsiz. "Eski İstanbul Kahvehaneleri”, Boxer Haziran 20I2, Sayı 96: 60-62. 
"Eski İstanbul Hikayeleri” adlı yazıdaki açıklama da yanlıştır:

“20’li yaşlarının sonlarında iki Amerikalı genç İstanbul'a gelirler...Allan Ramsay’nin İstanbul'a ilk gelişi değildir. Bir bakıma Cyrus'un rehberliğini yapacaktır. Cyrus, Allan'dan onlarca kahvehane hikayesi dinlemiştir ve bunların peşindedir” (s. 61).

Masalların iki yabancı seyyah tarafindan dinlenmesi, derlenmesi, ve kendi dillerine çevrilip bu tür masallara yabancı bir ülkede okuyucuyla buluşması önemsiz detaylar gibi görünse de bu masalların üç kıtaya yayılmış yolculuklarını anlamak için çok değerlidir. Bu anlamda iki yazarın kimler olduğunu, niçin İstanbul'da bulunduklarını ve neden bu hikayeleri derleyip bastıklarını doğru kaynaklardan öğrenmek gerekmektedir.

Cyrus Adler ve Allan Ramsay'nin 1890 yılında İstanbul'da bulunmaları ve kahvehaneleri birlikte ziyaret ediyor olmaları bir tesadüf değildir. Sultan Abdülmecid tarafından Tersane-i Amire'de görevlendirilmek üzere Aberdeen'den İstanbul'a davet edilen İskoç Alexander Ramsay, Allan Ramsay'nin babasıdır ${ }^{10}$ (s. vii). Tersane-i Amire'deki işinin üzerine bir de 1862 'de İstanbul'daki İngiliz Elçiliğinde Christina McGregor ile evlenen Alexander Ramsay ailesine İstanbul'da kalıcı bir hayat kurmuştur. McGregor ve Ramsay'nin oğlu Allan İstanbul'da doğmuş ve büyümüştür. Böylece Allan, ana dili İngilizce dışında Türkçeyi de iyi derecede konuşabiliyor ve yazabiliyordu. Cyrus Adler ile İstanbul'da yolları kesiştiği sırada Ramsay "19. yüzyılın son çeyreğinde" kurulan "çok uluslu bir yabancı sermaye yatırımı” olan Tütün Rejisinin yönetim kurulu üyeliği görevini yapıyordu ${ }^{11}$ (s. 116). Görevi gereği sık seyahat eden Ramsay zengin bir kültüre sahip Anadolu, Rumeli ve Arap Yarımadasındaki Osmanlı topraklarında çok seyahat etmiş, ve yine görevi gereği farklı sınıflarından insanlarla bir araya gelmiştir ${ }^{12}$ (s. vii). Bu seyahatleri sırasında birçok kahvehanede bulunmuştur ve buralarda anlatılmış çoğu birbirine benzeyen masallara hiç de yabancı değildir.

Sami Dilleri uzmanı ve din bilimci, Amerikalı Cyrus Adler'in 19. yüzyılın sonlarında İstanbul'da bulunmasının ise bambaşka bir hikayesi vardır. 1887 yılında Johns Hopkins Üniversitesi'nden Sami Dilleri uzmanlığını kazanan Adler 1890

\footnotetext{
IO McCullagh ve Ramsay, I9I4.

II Melda Yaman Öztürk ve Nuray Ertürk Keskin, "Osmanlıda Yabancı Yatırımlar: Duyunu Umumiye ve Tütün Rejisi”, Memleket Siyaset Yönetim, c.6 s.I6 20II/16.

I2 McCullagh ve Ramsay, I9I4.
} 
yılına kadar aynı kurumda öğretim görevliliği yapmışıır ${ }^{13}$ (s. 35). Sami dillerine olan tutkusu dışında Adler'in bir diğer ilgi alanı İncil'de bahsi geçen kültürlerin tarihini aydınlatmak amacıyla yapılan arkeolojik kazılardı. Bu ilgisi Adler'i 1888 yllında Smithsonian Enstitüsünün idaresinde olan U.S. National Museum'un (kuruluşundaki ilk ismiyle Amerikan Ulusal Müzesi’nin) Eski Uygarlıklar Bölümünün onursal müdürü yaptı. Ve Adler'in bu ilgisi ve atandığı bu görev 1890'da Amerikan Başkanı Benjamin Harrison'ın Adler’i Amerika Birleşik Devletleri'ni temsilen özel vekil olarak Osmanlı İmparatorluğu, Mısır, Tunus, Cezayir ve Fas’a göndermesine kapı açmıştır.

1893 yılında Amerika Birleşik Devletleri'nin Chicago şehrinde düzenlenecek olan World's Columbian Exposition'da (Dünya Kolomb Fuar1 veya Chicago Dünya Fuarı) bir çok ülkenin katıldığı ve kendi kültür ve folklorlarının tanıtımını yaptığı bir sergi düzenlenecektir ${ }^{14}$. Kristof Kolomb’un Amerika kıtasını keşfinin 400. yıldönümü Chicago'daki fuarda dünya folklorlarının tanıtımı ve birbiriyle etkileşimi ile kutlanacaktır ve Amerikan Başkanı Harrison yakın doğu ülkelerini bu kültürel şenliğe davet etmek için Adler'i elçi tayin etmiştir ${ }^{15}$ (s. 41). 1890 yıl Kasım ayında ülkesinden ayrılan Adler on beş ay boyunca Osmanlı İmparatorluğu, Misır, Tunus, Cezayir ve Fas'ta ziyaretlerde bulunur ve bu ülkelerin fuara katılmaları için diplomatik görüşmeler yapar. Hatta Adler’in Osmanlı Vezir-i Azamı Kamil Paşa ile yakın arkadaşlık kurduğu tarihçiler tarafından söylenmektedir ${ }^{16}$ (s. 42). İstanbul ve kahvehaneleriyle ve tabii ki kahvehane hikayeleriyle bu on beş ay süren diplomatik gezi sırasında tanışmıştır.

Hem Maya Kitap'ın bastığı çeviride, hem de çeviriyle aynı yıl yayımlanan iki kitap tanıtım yazısında bahsedilen Cyrus Adler'in "uzun yıllar İstanbul'da yaşamış arkadaşı Ramsay'den şöhretini duyduğu kahvehane hikayelerini derlemek üzere İstanbul'a " gelmiş olması doğru bir yargı değildir ${ }^{17}$ (s. 42). Adler görevli olarak İstanbul'a geldiğinde - 1890 yılının Kasım ayında New York'tan gemiyle ayrıldığına göre tahminen Aralık ayında İstanbul’a varmıştır - Allan Ramsay ile

I3 Abraham A. Neuman "Cyrus Adler: A Biographical Sketch", American Jewish Year Book, New York: 194I: 23-I44.

I4 Pensilvanya Üniversitesi, Herbert Kartz Yahudi Çalışmaları Merkezindeki Cyrus Adler Koleysiyonu, bilgi için bkz. http://www.library.upenn.edu/cajs/Adler.html

I5 Neuman, 194I.

I6 Bu görüşmelerin sonucudur ki I893 Chicago Dünya Fuarında Allan Ramsay Bedevi sergisi düzenlemiştir.

I7 Kaliç, $20 \mathrm{I2}$. 
tanışıyor muydu, yoksa İstanbul'da gerçekleştirdiği resmi ziyaretler sırasında mı Ramsay ile tanıştı bilinmiyor. Ramsay'nin İskoç ve Adler'in Amerikalı olduğu düşünüldüğünde İstanbul'da tanışmış olma ihtimalleri artıyor. Adler, 1898'de yazdığı kısacık önsöze şu cümleyle başlamıştır: "İstanbul'a yaptığım çeşitli ziyaretler sırasında kahvehanelerde anlatılan hikayelerle ilgilenmeye başladım” (s. 7). Adler'in bu ilgisi hikayelerin anlatıldığı dil olan Türkçeye hakim, ama aynı zamanda Adlerle de İngilizce iletişim kurabilecek, öncelikle İstanbul kahvehane kültürüne ve kahvehane müşterilerine, sonrasında ise genel olarak Osmanlı kültür ve tarihine aşina bir yoldaş - arkadaş bulmasını gerektirmiş olmalı ki, Ramsay Adler'e İstanbul kahvehanelerinde eşlik etmiştir. 1914'te İngiltere'de basılmış olan Tales from Turkey' in önsözünde yazar McCullagh de, Adler ve Ramsay'in İngilizceye çevirdiği birçok masalı Ramsay’in işi gereği Osmanlı topraklarındaki ziyaretleri sırasında uğradığ $\mathrm{k}$ kahvehanelerde birçok kez duyduğunu belirtmiştir ${ }^{18}$ (s. vii). Bunların bir kısmını Ramsay, Adler ile İstanbul'daki kahvehane ziyaretleri sırasında tekrar dinlemiş, bir kısmını da zamanında dinlediği ve hatırladığı haliyle Adler'e anlatmıştır.

Pertev Naili Boratav’a göre Türk kültürü ve Türk halk edebiyatı üç farklı kültürün kaynaşması sonucu oluşmuştur: Türklerin Müslüman olmadan önce eski yurtlarındaki komşu kültürlerden aldıkları ile kendi atalarından miras kalan geleneklerin toplamı bir Orta Asya kültürü; İslâm dinine girdikten sonra etkisi altına girmeye başladıkları Arap ve Müslüman-İran kültürü, ve yeni yurtlarındaki gelmiş geçmiş uygarlıklardan kalıntıların, çeşitli ırk, dil ve dinden olan kavimlerin geleneklerinin birleşimi bir kültür ${ }^{19}$ (s. 294). Boratav, Türk kültürü ve edebiyatının bu zengin yapısını en iyi gösteren eserlerin sözlü halk geleneğinde bulunduğunu ve maalesef bu geleneğin eserlerinin çok azının günümüze ulaşabildiğini belirtmektedir. Adler ve Ramsay'in kahvehane hikayeleri Boratav'ın kaybı için yakındığı o sözlü halk geleneğinin örneklerindendir.

Türk sözlü geleneğinde birçok anlatma türü vardır: "masallar, fikralar, latifeler, hayvan masalları, tekerlemeler, efsaneler, menkıbeler...”(s. 293). Boratav' in üzerinde durduğu ve kitabında birçoğuna yer verdiği Türk sözlü geleneğinin parçası masallar Adler ve Ramsay'nin 1890'ların başında kahvehanelerde dinlediği türdür. Matbaa baskısıyla en uzunu on sayfa olan bu kahvehane masallarının özel hikaye anlatıcıları, okuyucuları veya meddahlar tarafından anlatılıp anlatılmadığı kesin

I8 McCullagh ve Ramsay, I9I4.

I9 Pertev Naili Boratav. Az Gittik Uz Gittik, İstanbul: Adam, 1992. 
değildir. Adler kitabın önsözünde masalların kahvehanelerde nasıl bir ortamda anlatıldığı ile ilgili şunları belirtmiştir:

Önceleri bir iki kelime olarak başlayan konuşmalar sonraları genel sohbete döner. Sonunda o civarın bilge bir kişisi gelir ve herkes ona dönüp konuyu bağlamasını bekler. Bu da genellikle adamın bakış açısını tarif eden bir hikaye anlatmasıyla yapılır (Kaliç 2012: 5).

Bu kısacık nottan şu anlaşılmaktadır: kahvehanede masalları Türk sözlü geleneğiyle büyümüş bir Osmanlı efendisi anlatır. Bu kişi büyüklerinden ve çevresinden dünyevi veya manevi konularda öğütler veren hikayeleri çok dinlemiş ve ezberlemiştir. Vakti gelip kendisi anlatmaya başladığında da hikayeleri kendi zamanına uyarlamıştır. Yani, Adler ve Ramsay'nin bir araya getirip bastı̆̆ bu masallar meddah gösterilerinden veya aşık dinletilerinden alınmış hikayeler değildir. Bunlar, günümüzde örneğini çok sık görmediğimiz, hatta kaybolmaya yüz tutmuş bir Türk geleneği olan sözü bağlamak ya da sohbeti daha eğlenceli kılmak amaçlı hikaye anlatma geleneğinin parçası olan masallardır ve sözü bağlamak, öğüt vermek, kötülüğü yermek, iyiliği yüceltmek, ya da sadece eğlendirmek için anlatılırlardı.

Adler ve Ramsay'nin bu hikayelere "kahvehanede anlatılan hikayeler - Told in the Coffee House" adını vermesi hikayelerin kahvehane kültürü içinde yoğrulmuş ve hatta o kültürün vazgeçilmez bir parçası oluşuna işarettir. Kahvehanelerin vazgeçilmez parçası sadece hikayeler değildir elbette, başlı başına hikaye anlatma geleneği kahvehanelerde gelişir ve belki de bu geleneğin en yaygın olduğu kamusal mekanlar kahvehanelerdir. Gündelik hayatın dünyevi veya manevi sorunlarını ve bu sorunların olası çözümlerini, bu sorunlardan çıkarılan dersleri, ya da genel anlamıyla halkın yargılarını, yasaklarını, günah veya sevap olarak nitelediklerini içinde barındıran bu hikayeler Adler' in de belirttiği gibi "adetlerin, geleneklerin ve insanların düşünme yöntemlerinin niteliklerini belirtmesi açısından korunmaya değer hikayelerdir” (s. 7).

Cengiz Kırlı, Osmanlı İmparatorluğunda kahvehanelerin ve kahvehane muhabbetlerinin Osmanlı kültürünü ve sosyal yapısını anlamak için çok önemli bir yer tuttuğunu belirtmektedir. ${ }^{20}$ Kırlı’ya göre kahvehane, toplumun farklı sinıflarından, farklı mesleklerinden, hatta farklı dinlerinden "insanların konuşmak veya

20 Cengiz Kırlı, "Kahvehaneler: 19. Yüzyıl Osmanlı İmparatorluğu’nda Kamuoyu”, Osmanlı Kahvehaneleri: Mekan, Sosyallik ve İktidar (ed.) Ahmet Yaşar, İstanbul: Kitap Yayınevi, 2009, s. 95-II8. 
haber, bilgi ve düşünce alışverişinde bulunmak üzere bir araya geldikleri başlıca mekandı" (s. 96). Daha önce de değinildiği gibi, kahvehaneler toplumun her kesiminden insanın siyaseti konuştuğu, hatta fikir ayrımlarına düşüp tartıştığı mekanlar olmuştur hep. Kırlı, 19. yüzyılın ortalarında bu fikir ayrımlarını yakından takip etmek ve padişah ve yönetim hakkında olumsuz konuşanları cezalandırmak için Osmanlı kahvehanelerine hafiyelerin yerleştirildiğini belirtmiştir. Osmanlı arşivlerinde yer alan hafiye raporları - jurnaller bu bilgiyi doğrular niteliktedir (s. 106). Hafiye raporları gün içinde kahvehaneye gelen kişilerin kimliklerinden, konuştukları konulara kadar her detayı içermektedir. Hafiyelerin varlığının çok da gizli kalmadığı aşikardır; zira raporların bazıları gün içinde kahvehane müşterileri tarafından anlatılan masallarla-hikayelerle doludur. Hikaye anlatıcısı hikayenin karakterleri üzerinden gündelik hayata, siyasete veya Saray’a gizli gizli göndermeler yaparak fikrini beyan eder ve sohbeti derinleştirir. Yani hikayelerin siyasi yapıyı eleştiren, eleştirmiyorsa bile dönemin siyasi gelişmeleri ile ilgili dinleyiciye bilgi veren ve bunu da gizli ve nükteli bir dille yapan bir yanı da vardır. Cengiz Kırlı’nın da belirttiği gibi,

masal anlatmak, karmaşık bir süreçtir... masalın satır aralarında fantezi ve gerçeklik, gerçek ve hayali karakterler birbirinin içine geçer... masallar, gerçek sorunlar için hayali, ancak arzulanan çözümler sunar (s. 106).

Yani, kahvehanelerde sohbet sırasında anlatılan bu masallar Osmanlı sosyal yapısını, düşünme şekillerini, Osmanlı insanının gündelik sıkıntılarını, inançlarını, korkularını, ve sevinçlerini bu sözlü geleneğe yabancı büyüyen kuşaklara tanıtan en önemli kaynaklardan biridir.

Adler ve Ramsay'nin derlediği masalların kahvehane ortamında anlatılmış olmasının dışında elimizde masallarla ilgili detaylı bilgi bulunmamaktadır. İstanbul'un hangi semtindeki kahvehanelerde dinlendikleri, kimler tarafından anlatıldıkları ya da ne tür sohbetler sırasında anlatıldıkları bilinmemektedir. Önsözde Adler masallar "genellikle Arap veya Acem kökenlidir, ama Türk zihni onlara yeni bir biçim ve felsefe kazandırır"21 (s. 7) demiş ve masalları Arap, İran ve Türk üçgeninde değerlendirmemiz gerektiğini vurgulamıştır. Adler'in değindiği bir diğer kaynak ise Ermeni masallarıdır. Adler, kitaptaki iki masalın Ermeniceden çevrilmiş olduğunu söylese de hangi iki masal olduğunu belirtmemiştir. Önsözde üzerinde durduğu bir diğer önemli nokta ise masalların "hiçbir kitaptan veya yazılı

2I Adler ve Ramsay, I898. 
kaynaktan çevrilmemiş ve mümkün olduğunca anlatıldıkları gibi korunmalarına dikkat edilmiş" (s. 7) olmasıdır. Pek tabii ki bu göreceli bir yargıdır. Adler'in belirtmek istediği, derledikleri masalları yazılı bir kaynaktan değil de doğrudan anlatıcının ağzından öğrenmiş olduklarıdır. Yoksa elbette anlatıcı da bu masalları birilerinden duymuştur. Belki de anlatıcıdan çok önceki kuşaklar bu masalların metinlerini el yazmaları olarak yazıya geçirmiştir. İşte tam bu noktada Osmanlı kültürünün "hem sözle hem yazılı anlatımla" gelişmiş olduğunu savunan Mehmet Kalpaklı'nın Osmanlı kültürünü "sözel kültür” olarak tanımlamasına göndermede bulunmak gerekmektedir. ${ }^{22}$

Francis McCullagh, 1914'teki Londra baskısının önsözünde, bu masalların yağmurlu ve firtınalı gecelerde, soba ateşinin ışığında, yarı-han yarı-kahvehane olarak betimlenen mekanlarda anlatıldığı gibi bir de gündüz vakti, Musevinin de camii hocasının da, berberin de hamamcının da, polisin de dilencinin de uğradığı mahalle kahvelerinde anlatıldığını belirtmektedir ${ }^{23}$ (s. xv). Anlatıldığı zamanın ve mekanın, masalların anlattığı zaman ve mekandan daha önemli olduğunu savunan McCullagh, bu masallarla tanışmanın en güzel yolunun aslında onları bir İstanbul kahvehanesinde Türk bir anlatıcının dilinden dinlemek olduğunun altını çizmektedir (s. xxix).

Genel hatlarıla, Adler ve Ramsay'nin derlediği, daha sonra Francis McCullagh ve Ramsay'nin uzun bir önsöz ile tekrar basımını yaptığı bu masalların kahramanları çok çeşitlidir. Günde beş kez şeytana lanet eden demirci ustası, Musevi dönmesi Müslüman, emanet aldığı paranın siyah zeytinlere dönüştüğünü söyleyen Yahudi komşu, domuzuyla konuşabilen Papaz, padişahın baş müneccimi ayakkabı tamircisi, cennetten arazi satan müftü, Yahudi tefeci, Hıristiyan köyündeki açgözlü Türk seyyah, kurnaz kadın, adaletsiz kadı, düzenbaz uşak, rüşvetçi şeytan, Yahudi tarafından dolandırılan Ermeni tüccar, karısını dayakla iyileştiren çiftçi bunlardan bazılarıdır. Masallarda ortak bir konu mevcut değildir. Masalların konuları, kadın ve erkeğin farkı, ticari ilişkilerde güven ve dini ilişkilerde maneviyat gibi çok genel çerçeveler içine yerleştirilebilir. Kadın ve erkek ilişkilerinde kadının keskin zekaya sahip olması, kurnazlığı, ama aynı zamanda diline sahip olamayıp boşboğazlık etmesi, boşboğazlığı nedeniyle kocasını konu komşuya rezil etmesi, kadının gözünün yükseklerde olması, şana, şöhrete ve paraya düşkün olması ve

22 Mehmet Kalpaklı. "Evliya Çelebi Seyahatnamesi ve Osmanlı Kültürünün Sözelliği / İşitselliği”, Evliya Çelebinin Sözlü Kaynaklar, Ankara: Unesco Türkiye Milli Komisyonu Yayınları, 2orz: 85-90.

23 McCullagh ve Ramsay, I9I4. 
fazla meraklı olması masallarda yer alan kadın karakterlerin özelliklerindendir. Ticari ve komşuluk ilişkilerinde işlenen en göze çapan temalar güven duyup duymamak, yalan söylemek, dolandırmak ve açgözlü olmak olarak sıralanmaktadır. Maneviyat ilişkilerindeki ana temalar ticari ilişkilerdeki temalarla çok benzerlik göstermektedir. Cennetten dönüm satarak masum insanları kandıran müftünün ve çöpçünün hayatı boyunca biriktirdiği paranın üstüne yatan adaletsiz kadının hikayeleri din adamlarının dahi dürüstlük ve adalet yolunda gitmediklerini vurgulamaktadır. Farklı din ve milletten karakterlerin aralarındaki anlaşmazlıklar birçok masala konu olurken, masalların bütünü göz önüne alındığında belli bir din ve milletin devamlı olumsuz sıfatlarla resmedilmesi söz konusu değildir. Yani, Musevi, bir masalda dolandırıcı komşuyu canlandırırken, bir diğerinde dolandırıcı müftünün oyununa gelen tefecidir. Birbirine çok da zıt olmayan örneklemeler olsa da bir masalda suçluyken diğerinde mağdur olmaktadır. Genel hatlarıyla masalların kıskançlık, aldatma, parasızlık, geçim derdi, güvensizlik, aç gözlülük, adaletsizlik, kurnazlık gibi dünyevi konularla ile ilgili olduğu söylenebilir.

\section{Hikaye: "How The Hodja Saved Allah"}

Son olarak, 1890-1891'de İstanbul'da bir kahvehanede muhtemelen bir Türk'ün ağzından dinlenen, 1898'de Told in the Coffee House kitabiyla New York'ta okunan, 1914'te Tales From Turkey kitabiyla bu kez de Londra okuyucusuyla buluşan, ama, maalesef ki 2012 yılında İstanbul 1898 Kahvehane Hikayeleri basilırken dillendirildiği dile, yani Türkçeye çevrilmemiş, unutulmuş, sansürlenmiş bir masaldan söz etmek isterim; How the Hodja Saved Allah (Hoca Allah'1 Nasıl Kurtardı). İstanbul 1898 Kahvehane Hikayeleri 28 hikaye olarak basılmıştır. Halbuki orijinal hali, yani Told in the Coffee House: Turkish Tales kitabı 29 hikayeden oluşmaktadır. Kitabın orijinal halinde ilk masal olan How the Hodja Saved Allah kitabın çevirisinde hiç yer almamıştır. Yayınevi tarafından mı yoksa çevirmen tarafından mı bu masalın çeviri kitaba dahil edilmesi sakıncalı bulunmuştur bilinmemektedir; ancak şu aşikardır ki, kitabın çevirisini yapan Maya Kitap ve Sabri Kaliç ile kitabın tanıtımını yapan gazete-dergi yazıları kitabın orijinalini kaynak göstermek nezaketinde bulunmamışlar ve 29 masaldan birini tamamen unutulmaya bırakmışlardır.

How the Hodja Saved Allah hikayesi bir camii hocasının bir gün öğrencilerine Bakara suresinin 261. ayetini okurken "ilahi bir gücün hocanın manevi gözünü açması” ile başlar ${ }^{24}$ (s. 2). Bakara suresinin 261. ayeti şöyle buyurmaktadır:

24 Adler ve Ramsay, 1898. 
"Mallarını Allah yolunda harcayanların durumu, yedi başak bitiren ve her başakta yüz tane bulunan bir tohum gibidir. Allah dilediğine kat kat verir. Allah lütfu geniş olandır, hakkıyla bilendir"25 (Birebir tercümesi olmasa da Adler ve Ramsay de hikayede Bakara suresinin 261. ayetine yer vermişlerdir). Yaşadığı aydınlanma sonucu hoca, Allah yolunda harcanan her kuruşun katbekat geri geleceğini ve bunun çok karlı bir yatırım olacağını düşünür. Bugüne kadar yüzlerce kez okuduğu bu ayetin anlamını gözden kaçırdığı için hayıflanan hoca, öğrencilerini evlerine gönderir göndermez sokağa çıkıp elindeki tüm parasını fakir ve muhtaç insanlara dağıtır. Hesaplamalarına göre Allah’’n yoluna yaptığı yatırım hocaya 1000 kuruştan az kazandırmayacaktır.

1000 kuruşun heyecanıyla hoca öğrencileriyle derslerini bile iptal ederek paranın gelmesini evinde beklemeye başlar. Ancak Allah'ın ona sözünü verdiği 1000 kuruştan haber yoktur. Üçüncü günün sonunda hocanın elinde hiç para, evinde de hiç yiyecek kalmamıştır. Aç ve parasız hoca ümitsizce şehirden uzaklaşıp kimsenin onu duyamayacağı ıssı bir yerde Allah'a yakarmaya, kaderine lanet etmeye başlar. Tam da o sırada uzun saçlı, korkutucu, feryatları yeri göğü inleten "Fakir Derviş" görünür. Hoca, başına gelenler yetmezmiş gibi bir de Fakir Dervişe yakalanıp canından olmak istemez ve hemen bir ağacın üzerine çıkıp saklanır ve Allah'a ona yardım etmesi için yalvarmaya başlar. Derviş kendi kendine

Neden dünyaya geldim ki? Atalarım neden dünyaya geldi ki? Neden insanoğlu dünyaya geldi ki? Of Allahım, of Allahım! İnsanoğluna ıstıraptan başka bir şey vermedin. Atalarımın çektiği ıstırabın intikamını ben almalıyım ${ }^{26}$ (s. 6).

demekte ve hoca bunları dinlemektedir. Derken, Derviş çantasını açar, ve içinden sırayla Hz. Eyyub, Hz. Davud, Hz. Süleyman, Hz. İsa ve Hz. Muhammed'in figürlerini çıkartır. Sonsuz sabrıyla insanlığa örnek olan Hz. Eyyub’u insanları kandırmakla ve göründüğü gibi sabırlı olmayıp zor anında Allah’a lanet etmekle suçlayan Derviş, Hz. Eyyub’un figürünü eline alıp uzun kılıcıyla kafasını keser. Derviş, sesinin güzelliğiyle ünlü Hz. Davud'un insanları, faziletli ve dürüst bir hayat süren karşılığını muhakkak alacaktır diyerek kandırdığını, cinler ve yeryüzündeki yaşayan her türlü canlıyla konuşabildiğine inanılan Hz. Süleyman’ın ise insanlara ıstırap ve yıkımdan başka bir şey getirmediğini ileri sürerek onların

25 Halil Altuntaş ve Muzaffer Şahin. Kur’an-ı Kerim Meali, Ankara: Diyanet İşleri Başkanlığı Yayınları, 2006.

26 Adler ve Ramsay, I898. 
figürlerinin de kafalarını keser. Sonrasında da, Hz. İsa ve Hz. Muhammed'in anlatılarının insanları birbirine kırdırdığını, bu kıyımların nehirlerin suyunun kan kırmızı akmasına yol açtığını ve dünyada barış ve huzurun kalmadığını gerekçe gösteren Derviş onların da figürlerini eline alıp kafalarını keser.

Son olarak, Derviş çantasından bir figür daha çıkartır. Bu figürün, her şeyin tek yaratıcısı olan Allah olduğunu vurgular ve onunla konuşmaya başlar. Yaptıkları yanlışlar ve insanlığa kötü örnek oldukları gerekçesiyle sırasıyla Hz. Eyyub, Hz. Davud, Hz. Süleyman, Hz. İsa ve Hz. Muhammed'i cezalandırdığını söyleyen Derviş, cezalandırılma sırasının bu peygamberlerin yaratıcısına geldiğini belirtir. Derviş tam da kılıcını çıkartıp savuracakken hoca bütün cesaretini toplayıp saklandığı yerden "dur, dur, onun bana 1000 kuruş borcu var" (s. 11) diyerek çıkar. Hocanın yüksek sesinden irken ve korkan derviş olduğu yere yığılıp kalır. Hoca, Dervişin ölmüş olduğunu anlar ve karnı o kadar açıır ki Derviş่in para kesesinden para alıp uzaklaşmak ister. Keseyi eline aldığında ağır olduğunu fark eder ve Derviş'in parasını sayar. Kesede tam 1000 kuruş vardır. Hoca nüktedan bir tavırla "ey Allahım, sözünü tuttun, bana 1000 kuruşumu verdin, ama bunu senin hayatını kurtardıktan sonra yaptın" (s. 12) diyerek evinin yolunu tutar. 